Green's address on the cinema and handicraft training directs attention to the need for investigation in the technique of using the film in schools.

\section{The Hebrew University, Jerusalem}

THE Hebrew University, on the heights of Scopus in Jerusalem, is developing fast and well. Begun in 1923 with a Chemistry Research Institute, it is to-day a centre of research and instruction, with faculties in the main branches of learning, an academic staff, including research workers, of 125 , and a students roll, underand post-graduate, of 850 . More than 30 per cent aro women. Hebrew is the language of instruction. In some Departments aro men pre-eminent in their own academic field. Prof. Bernhard Zondek, professor of gynxecology, is in charge of the Hormone Research Laboratory which is now attached to the new Medical Centro opened in May of this year. Prof. S. Adler, head of the Microbiology Department, has already achieved an international reputation for his pioneer work on tropical diseases transmitted by parasites, and has undertaken several expeditions on behalf of the Royal Society. Prof. A. E. Fraonkel, formerly of the Universities of Marburg and Kiel, is one of the professors in the Mathematics Department, with mathematical philosophy and foundations of theory of sets and of analysis as his special field. The Archæological Department, under Prof. L. A. Mayer, works in close association with the Department of Classics.

Two new faculties have been added this year, a medical faculty-it was formerly only a pre.facultyand agriculture. The new professor of agriculture is Prof. E. Volcani, director of the Experimental Research Station at Rehovoth. The Hebrew University has played its part in enabling academic refugees to continue their work. Already nearly fifty exiled German scholars have been found positions at the University. These include Prof. H. Torczyner, the interpreter of the Lakhish Letters, Prof. J. Guttman, the authority on Jewish medieval philosophy, Prof. Martin Buber, the social philosopher, Prof. B. Zondek, the gynæcologist, Prof. Halberstadt, the radiologist, and the brothers Adelbert and Ladislaus Farkas, who aro directing the Department of Physical Chemistry. The work already done gives promise that perhaps in the not-distant future Jerusalem will once again become the centre of learning in the Near and Middle East.

\section{University and Professional Standards in the U.S.A.}

THE formulation of standards in respect of such matters as entrance and graduation requirements, staff, equipment and financial resources, and the accrediting of educational institutions with reference to them, are undertaken in the United States by voluntary national and regional associations and by State universities and departments of education. Lists of accredited institutions aro published from time to time and the situation is reviewed by the United States Office of Education once in every four years. Bulletin No. 16, "Accredited Higher Institutions, 1938" (Supt. of Documents, Washington,
D.C., pp. 212 ; 20 cents) brings together the latest available lists and standards of both voluntary and State accrediting agencies. Tho most noteworthy development of the past few years is the drawing up by the Engineers' Council for Professional Develop. ment of a statement of principles (reproduced in the Bulletin) for accrediting engineering curricula with the object of improving the status of the engineering profession. Other national associations have pub. lished lists of accredited professional and technical schools of law, theology, medicine, pharmacy, osteopathy, optometry, music, architecture, business, librarianship, journalism, forestry, social work and teaching. A National League of Nursing Education is conducting a survey with tho intention of issuing a list of accredited schools on its completion. Of tho university accrediting agencies, the chiof and most exclusive is the Association of American Universities, which regards as the principal ground for the inclusion of a college in its approved list, evidence of success "in stimulating scholarly interest in its students and in preparing them for moro advanced scholarly endeavour".

\section{The Carnegie United Kingdom Trust}

Twenty-FIve years have elapsed since Mr. Carnegio founded, with a capital of ten million dollars, his Trust "for the improvement of the well-being of the masses of the people of Great Britain and Ireland", and the Trustees preface their report for the year 1938 with a brief retrospect, in the course of which the allocation of their revenues since the Trust's foundation is sum. marized under the headings: libraries $£ 1,393,000$, physical welfare and playing fields and play centres $£ 471,300$, rural development and social service (in.

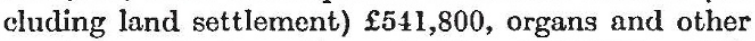
musical and dramatic activities $£ 330,500$, adult education $£ 66,600$, other activities $£ 339,500$. In pursuance of Mr. Carnegie's injunction to remember "that new needs are constantly arising as the masses advance" the Trustees aim at fulfilling the role of a pioneer body, financing no enterprise for more than a limited period, during which its sponsors aro oxpected to contrive means for maintaining it, should its continuance appear expedient, without further recourse to the Trust. This principle plays a decisive part in the framing of the programmes of constructive experimental work which are drawn up by the Trustees once in five years and which pre-determine the bulk of the expenditure of each year's budget.

THE current programme covers activities classified as : $(a)$ cultural and $x$ sthetic developments, including libraries, museums, music and drama, adult education; (b) social services, in many of which the National Council of Social Service collaborates, including village halls, community councils, shows and exhibitions, university settlements, village colleges, women's institutes, Zoological Society's films, national parks, youth services, etc.; and (c) land settlement. One of the notable events of the year was the publication of a report in furtherance of the policy inaugurated ten years ago for developing the educational function of museums of the British 